\title{
Nonchronically Sun-exposed Site
}

National Cancer Institute

\section{Source}

National Cancer Institute. Nonchronically Sun-exposed Site. NCI Thesaurus. Code C129467.

An area of the body subjected to inconsistent sun exposure. 